\title{
伊藤薫紀
}

\section{What is the Genuine Occlusion Regarding Tolerance?}

Shigeki Ito

The human body has tolerance. Because of the tolerance, the ideals cannot be sometimes seen. What is the genuine occlusion we should have? The author believes that natural dentitions which do not have occlusal wear are a key factor in the genuine occlusion. This article will discuss the genuine ideal occlusion observed in natural dentitions that do not have occlusal wear.

人には許容性というものがある。しかしこの許容性により，真実が見えなくなってし まっている現状もある。人体の求めている真の咬合とは一体どういう姿をしているのか？

筆者は一番理想的な咬合を咬耗の生じない咬合状態と位置づけ, 咬耗の生じていない天 然㐘列を細かく観察することにより，真の咬合の姿の解明に挑む。

Key words : 真の咬合 the genuine occlusion, 許容性 tolerance, 咬耗 occlisal wear, 天然歯列 the natural dentition，後方へのシフトの制御 Retrusive Barrier 

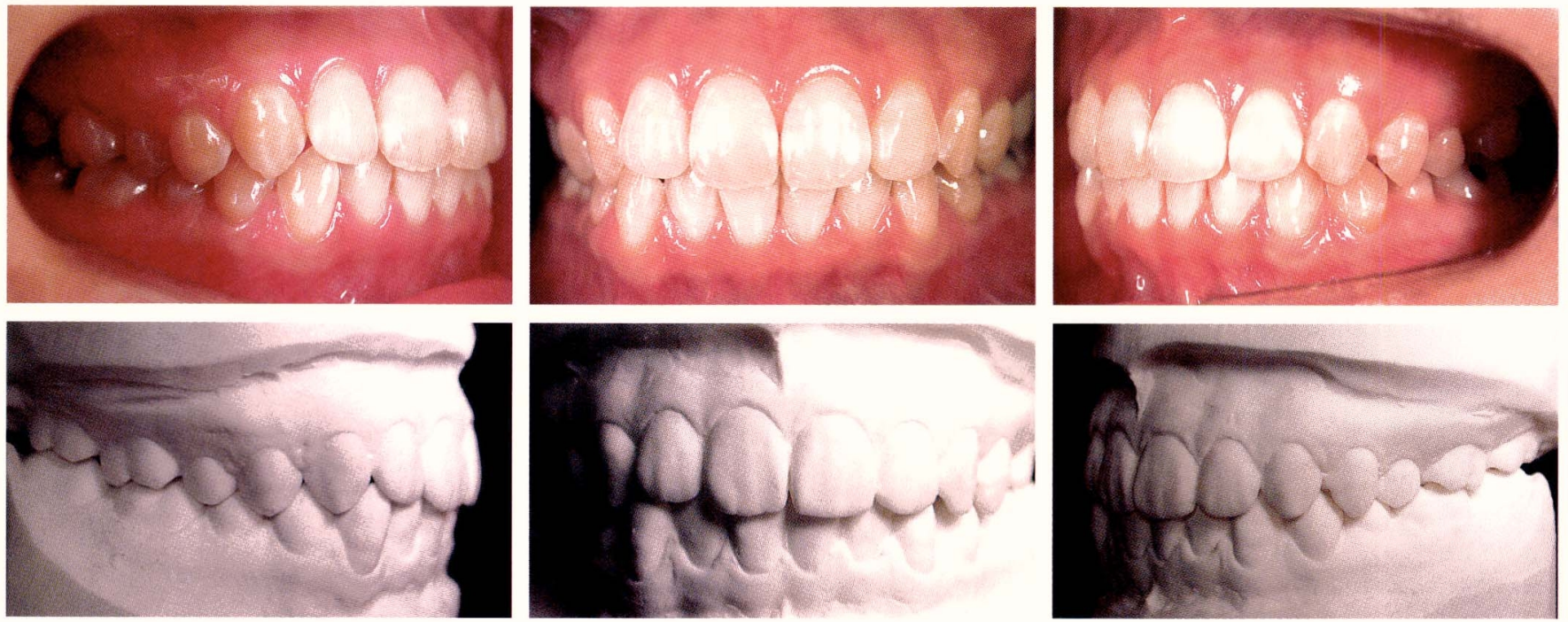

図 1 矯正経験のない咬耗の生じていない天然歯列

図2 右側方歯列.

図 3 右側上下第一大臼歯の咬合接触状態.
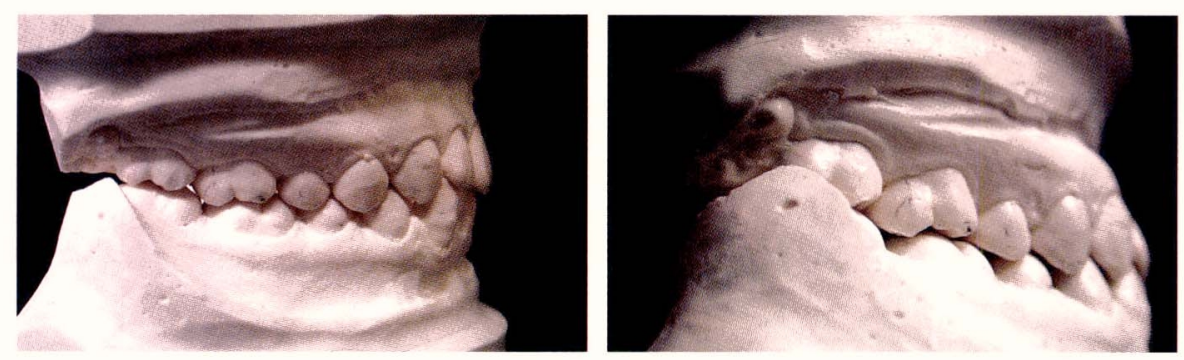

\section{緒言}

ものには必ず正常と言われる状態が存在する。毛正常 でない状態を異常と呼び, できれば正常もしくはそれに近 い状態にしたいものである。生理が理解できて病理を理解 できるのであり，正常がどういうものであるかを理解でき ていなければ当然異常を治すことはできない.

では正常な咬合とはいったいどういう状態をいうのか. 人には許容性というものがあり，多少の誤差，時には大き な䛊差でさえも容認してくれることがままある。ただその 場合, 痛みもしくは不快感はなくても, 歯牙を含む顎口腔 系には必ず変化は起こっている。このことを Compensation (代償) というが，できればこの代償も起こらなければよ り良い。代償にはA Articular Compensation（顎関節における 代償), Dento-Alveolar Compensation（歯・歯槽による代償）, Vertical Compensation（垂直的代償）などがあるが，筆者 は咬耗を歯による代償であるものとし，咬耗の生じていな い咬合状態が正常咬合の真の姿であると定義づけ，咬耗の 生じていない天然歯列を細かく観察することにより真の㖫 合接触状態とその意味することについての概念を書す.
今回観察した天然歯列は当医院に平成 10 年 9 月来院以 後平成 17 年 6 月までで一切咬耗の生じていない29才女性 の日本人のものである(図 1 ).

われわれは理想咬合の必要十分条件として長期にわたる 歯列の安定・維持のために, 歯牙の咬頭頂, 中心窩の連続 性および隣在歯との辺縁隆線の一致などをあげてきた。し かしながら矯正治療を受けたことがない天然歯列をよく観 察すると必ずしもその条件を満たしていない.というより は部位によってはほとんど異なっている。

まず上下第一大妇歯の咬合接触状態であるが，上䪽第一 大臼歯は極端に近心傾斜している (図己). よって当然上 顎第二大臼歯との辺縁隆線は一致していない.上顎第一大 白柬の㚘側遠心咬頭隆線が下顎第一大臼歯煩側遠心咬頭外 斜面と遠心咬頭外斜面の問の煩側遠心溝に前下内方に被さ るように接触している(図3).

一見このような咬合状態であると作業側側方運動時に咬 頭干渉が生じると思ってしまうが, 実際は, 咬頭干渉は生 じない. その理由は下䯪第一大田歯の特徽的な形態にある。 アングルのI級では作業側側方運動時の滑走面は下顎煩側 咬頭外斜面と上顎煩側咬頭内斜面の間で生じるので，まず 


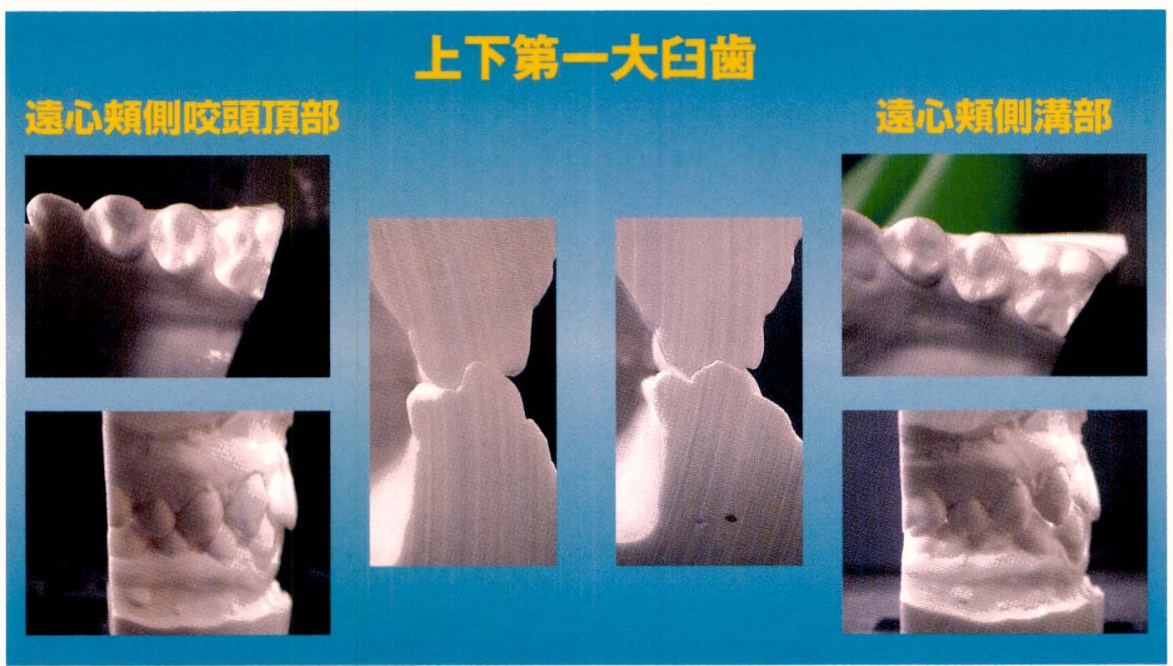

図4 右側上下第一大兒歯の切断面.

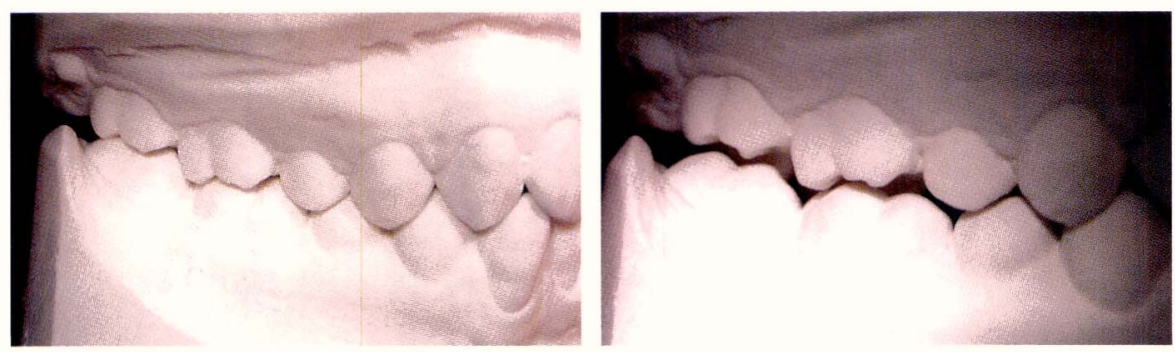

図 5 咬頭嵌合位と作業側運動時.

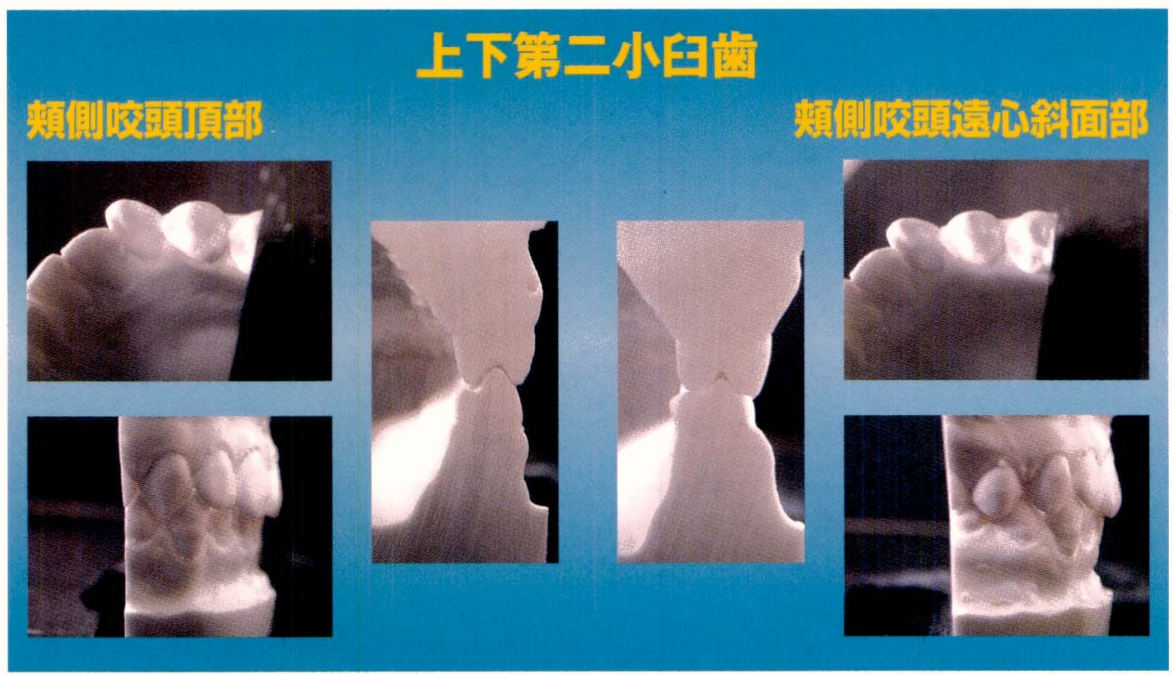

図 6 右側上下第二小臼歯の切断面

下顎第一大臼歯の㚘側咬頭外斜面から分析する。この歯牙 の特徵的なことは, 煩側遠心咬頭の中央から近心と遠心と で外斜面の咬頭傾斜角が異なっていることである (図4). この咬頭傾斜角の違いが上顎㚘側遠心咬頭の落ち达みによ る咬頭干渉を回避している（図５）。この咬合接触状態の 意味するところは，顎の後方へのシフトの制御であると推 測する。生体が一番拒絶するのは, 顎の後方へのシフトと 筆者は考えている。 その根拠はアングル III 級の人の咬合状
態はきわめて咬合論からかけ離れているのにもかかわら ず，TMDがきわめて少ない，上顎智歯挺出抜歯後に生じ るTMDなどである。顎の後方へのシフトの制御に関して はまた後に記す。

次に上下顎第二小目歯の咬合接触状態であるが，前述し た第一大臼歯に酷似している。下顎第二小臼歯煩側咬頭外 斜面も中央を境に近心と遠心とで咬頭傾斜角が異なってい る (図 6). 緩やかな遠心外斜面に上䫌第二小臼歯の㚘側 


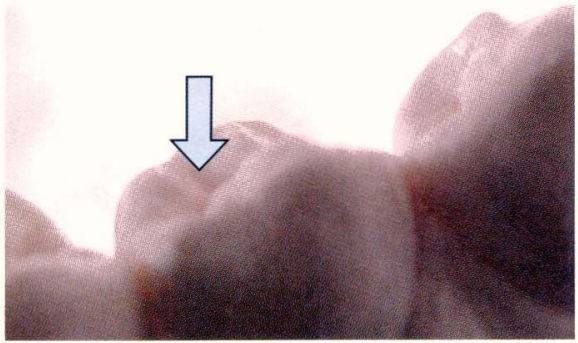

図 7 トーマスノッチ.

図 10 右側第一大臼歯と左側犬歯の咬頭勘合 状態.
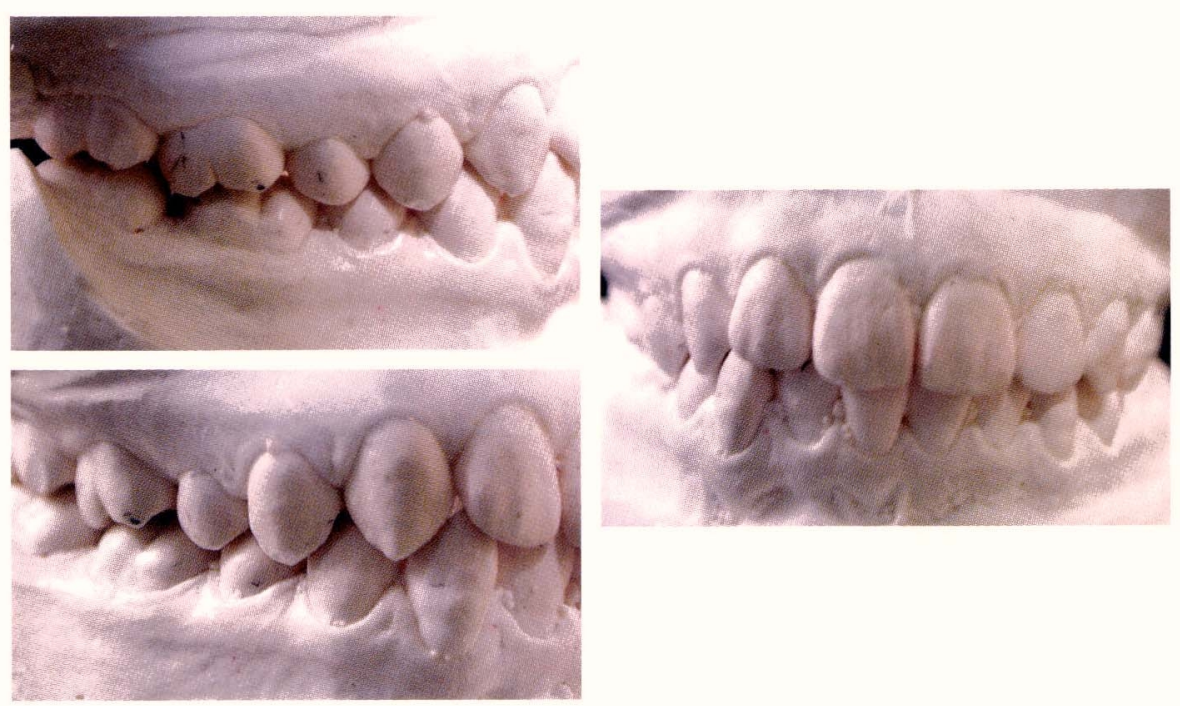

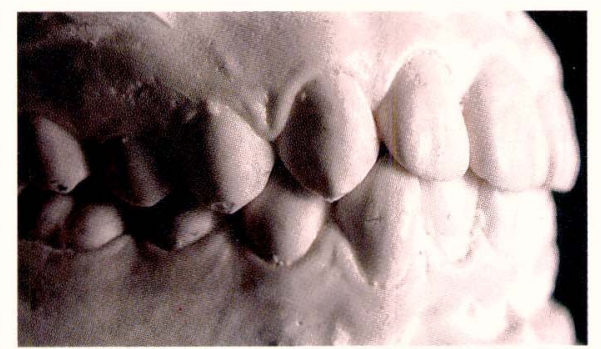

図 9 右側上下第一小臼歯咬頭勘合状態.
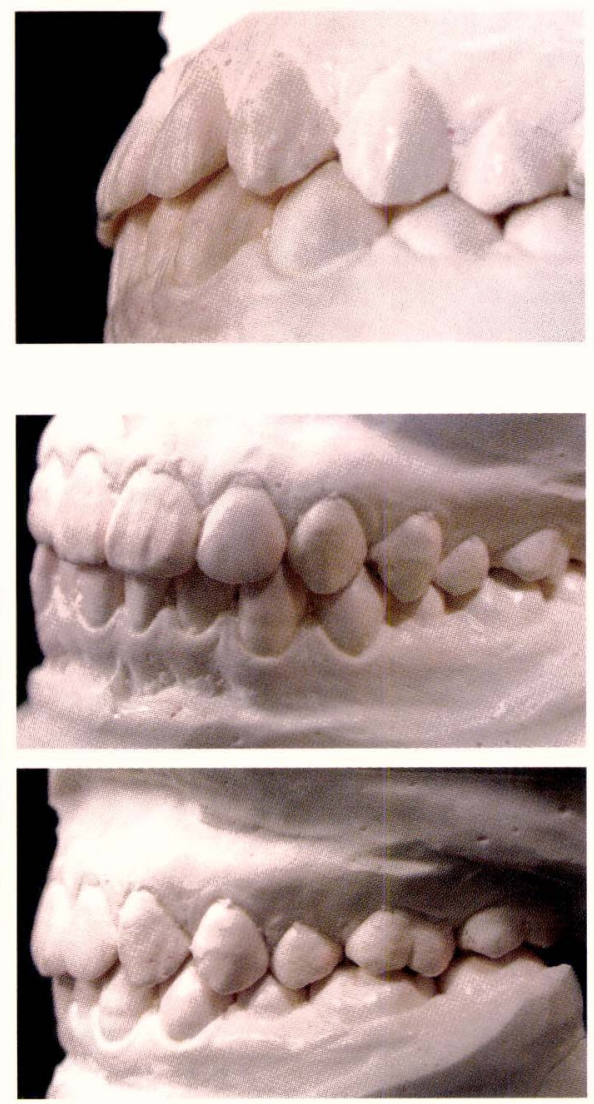

図 11 咬頭嵌合位の全歯接触状態.

峧頭隆線が前下内方に接触している，遠心外斜面をよくみ ると下顎第一大臼歯煩側遠心溝に似たくぼみがある（図 7). トーマスノッチとは下顎第一大臼歯煩側遠心溝の縮 小版と推測できる。そしてこの接触状態も顎の後方シフト の制御であると推測する。

下㖽第一小目歯にも㚘側咬頭遠心外斜面切端近くにはや はり咬頭傾斜角の緩い面が存在し（図 8)，そこに上顎第 一小臼歯の煩側咬頭隆線が接触しているが, その範冊はき わめて小さくなっており, 逆に咬頭の高さが増して犬歯に 近い咬合関係になっている（図９）.

犬歯を含めた前茵はアンテリアガイダンスとして下䪽を
上顎が前方および側方からサポートしている。

第一大臼歯の咬合関係は, 上顎犬歯が下顎犬歯を後下内 方に接触しているのに対抗するように上顎第一大白歯が下 顎第一大自歯を前下内方に接触している (図 10). 第二 小目歯は第一大臼柬に近い意味合いの接触関係であり，第 一小目歯は犬歯に近い意味合いの接触をしている.

第一大田歯から反対側の第一大巨歯まで下顎歯牙を上顎 歯牙が後下内方〜前下内方～前方〜前下内方～後下内方と サポートしている(図１１）。

また第二大臼歯の咬合接触関係は, 一歯対一歯咬合であ り，上顎第二大妇歯の特徵は上顎第一大臼歯と比較して㚘 


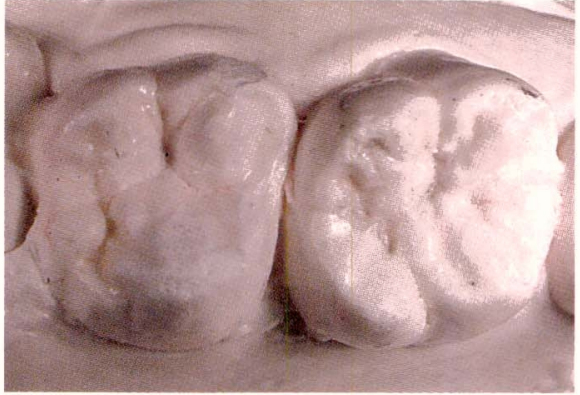

図 12 上顎第一大臼歯と第二大臼歯の咬合面 観、第一大臼歯と比較して，第二大臼歯の近心 頬側咬頭がきわめて発達しているのがわかる.

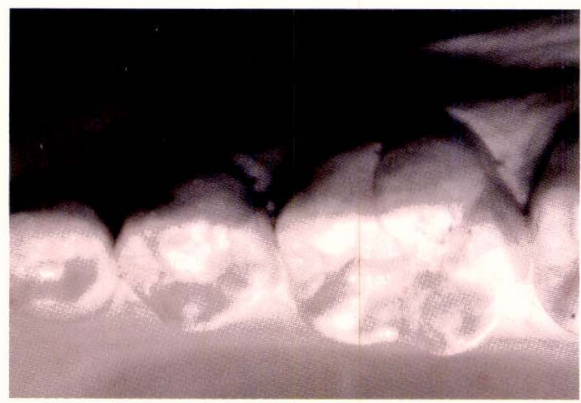

図 15 近心頬側咬頭は犬歯尖頭，第一第二小 臼歯頬側咬頭頂と連続性を帯びている。

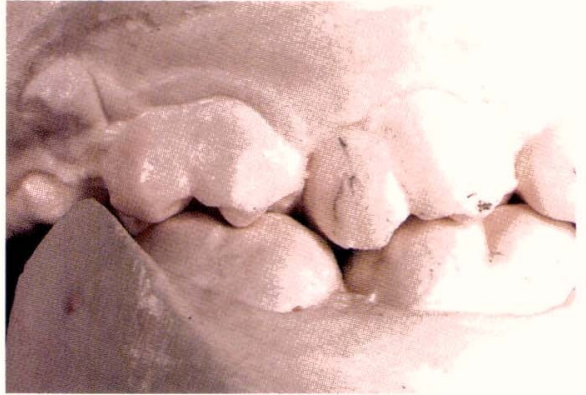

図 13 上下第二大臼歯の咬合接触状態。発達 図 14 下顎第一大臼歯咬合面観。頬側咬頭頂

した上顎近心煩側咬頭隆線が，下顎の煩側溝に の位置は揃っていない. しっかり咬み込んでいる

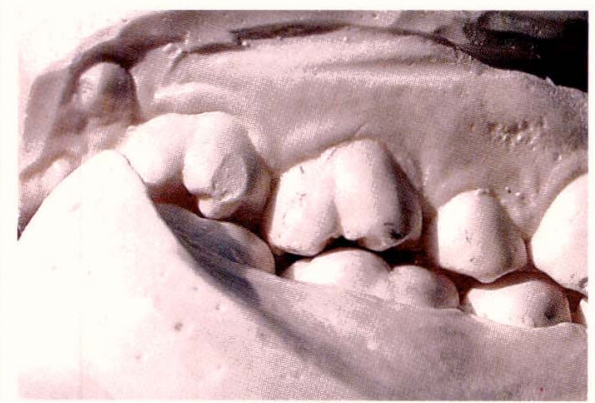

図 16 頬側遠心咬頭は上顎第一大臼歯の中心 窩に咬み込む。
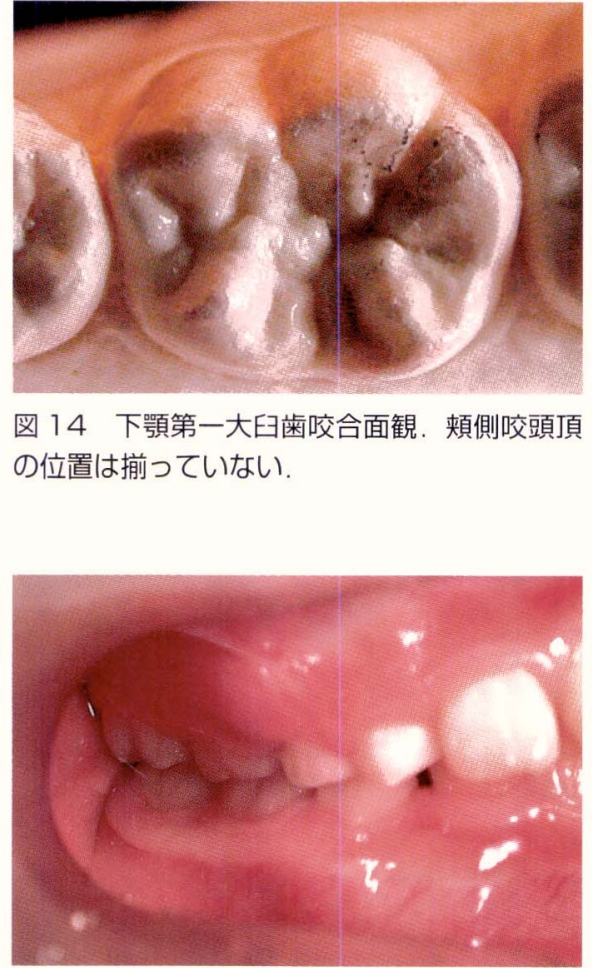

17 乳臼歯の咬合接触状態. 永久歯と同じ ように下顎の後方へのシフトを制御するような 接触関係を呈している.
側近心咬頭隆線がきわめて発達していることである（図 12).この発達した㚘側近心咬頭隆線が下顎第二大臼歯の 煩側溝に被さるように接触することにより, クロージャー ストッパー・イコライザーの役割を果たし, 顎の安定に参 加している（図 13）。

以上のことから，真の咬合とは咬頭嵌合位において水平 的に下顎を安定させるためにあることが推測される。咬合 接触状態も，ただ 3 点だとか 6 点で接触していればよいと か, 咀嚼能率向上のためにシャープな咬頭傾斜で臼歯離開 咬合であればよいなどという漠然としたものではなく，歯 牙一本一本がその形態を生かしながら顎安定のために決め られた部位同上が密に接触している。

この密接した咬合接触状態であるにもかかわらず咬耗が 生じていない現実があるのは, 咬頭嵌合位において顎位の 安定がいかに重要であるかを物語っている。そこに少しで も遊びがあると顎の安定が損なわれ, その情報は中枢神経 系に伝達され垂直化していた咀嚼パターンが乱れ, 水平化 することにより咬耗が生じると推測する。

前述した上下顎第一大臼歯の咬合接触状態が真の咬合状 態であるということの根拠を下顎第一大臼歯の特異的な歯 牙形態から解説する.
それは煩側 3 咬頭の位置関係に見られる。この3 咬頭の 位置は連続性を伴っていない(図 14)。まず煩側近心咬 頭.この咬頭は 3 咬頭の中で一番舌側よりに存在する。 しかし犬歯尖頭から第二小印歯と一緒にみると, この位置 で犬歯からの連続性に一致している(図 15). 㚘側近心 咬頭はこの位置にいることで上顎第二小四歯とのバランス をとっている，次に㚘側遠心咬頭ここの咬頭は逆にかなり 㚘側に位置している。機能咬頭として咬頭の高さだけでな く厚みもしっかりあり, 上顎第一大妇歯の中心窩に咬み込 んでいる（図 16)。近心傾斜し，かつ遠心に若干ロー テーションしている上顎第一大臼歯の中心窩に咬み込むた めには, 下顎第一大臼歯の㚘側遠心咬頭は一見かなり煩側 に位置していると思われがちなこの位置でないと咬み达む ことができない. 最後に遠心咬頭.この咬頭は舌側に位置 L, 上顎煩側遠心咬頭の落ち込みを受け止めている。

上下第一大臼㐘はこのようにバランスを保っており,こ の咬合状態でのみ安定し, 他の咬合状態では安定しない. 以上のことから前述した咬合接触状態が本来の咬合状態で あると推測できる。

上下第一大臼歯の咬合接触状態に象徵的にみられるよう に, 曰歯の咬合には咀嚼機能の他に顎の後方へのシフトを 

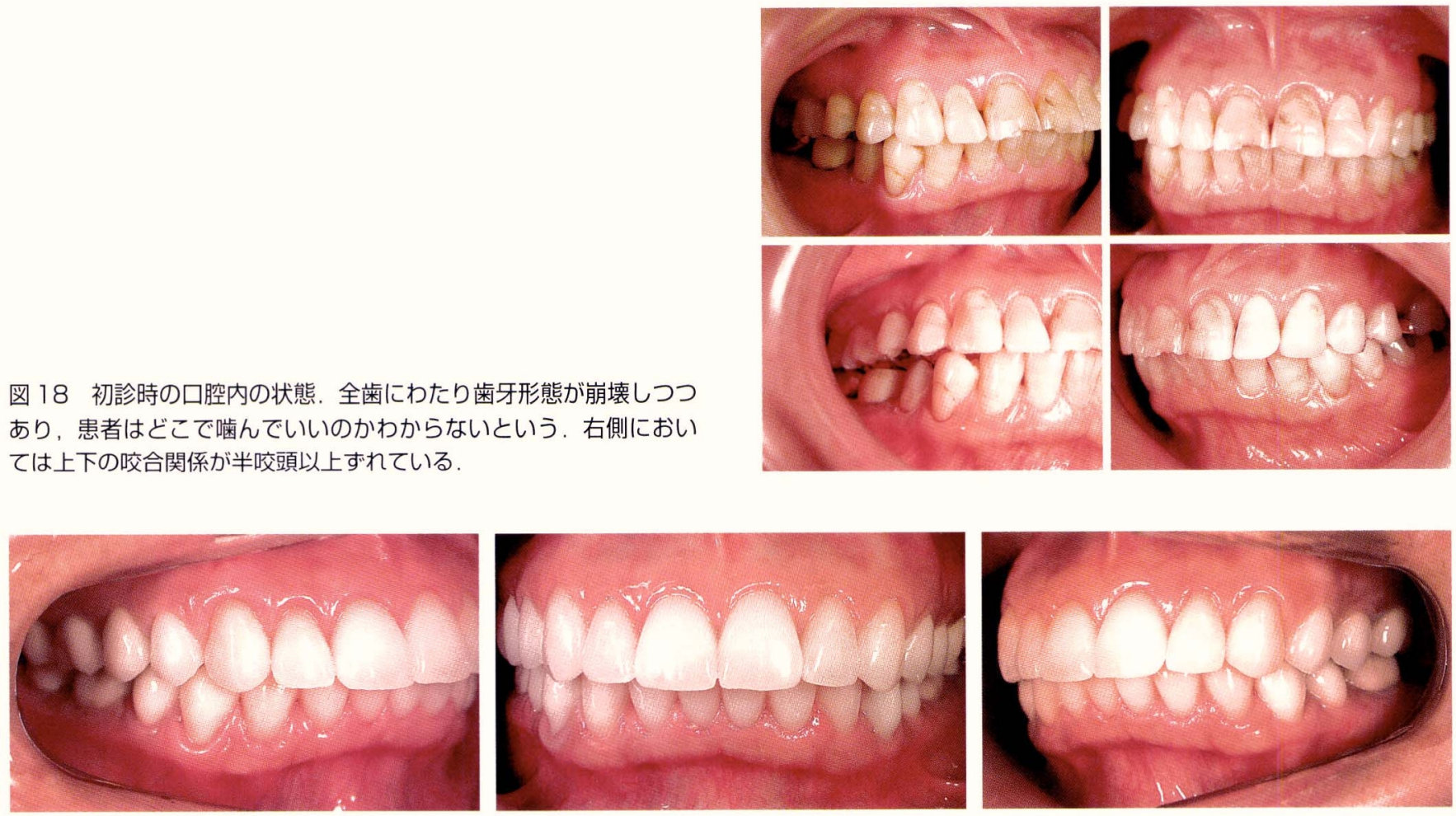

図 19 術後 4 年後の咬合接触状態. 咬合面もすべてセラミックであるが破折などは起こっておらず, 安定している.

制御する機能を有している。この後方へのシフトの制御は 乳臼歯にもみられる (図 17 )。上下第二乳臼歯の形態は 上下顎第一大䑔歯と酷似しており，咬合接触状態も同じで ある、第一乳臼歯では下顎第一乳臼歯の形態は㚘頁側咬頭の 遠心外斜面がきわめて広く，そこに上顎第一乳臼歯の近遠 心に広い㚘頁側咬頭が接触している。その範囲は永久㐘では みられない広さで, 接触面の角度は後下内方というよりは 側方に近いが，若干後方から押さえているように見受けら 机る。幼児期はストレスが多く，よってほとんどがブラキ サーであると報告されている。まだ顎関節の構造が完成し ていない幼児期にとって，下顎が後方にシフトすることは その後の顎関節に大きな德影響を及ぼすことが懸念され る、乳且歯および第一大田歯の後方へのシフトを制御する 咬合接触状態は未完の顎関節を守るためにあると推測さ れ，それは完成した成人の顎関節の機能および構造を維持 するためにも必要不可欠と言えるのではないか.

頡が後方へシフトするということは，関節窩内に括いて 下顎頭の後方へのシフトを意味し, 結果として関節円板前 方転位を引き起こすこととなる。関節门板前方転位という 言葉から関節円板自体が前方に転位すると思いがちだが， 実は関節円板が前方に転位するのではなく下顎頭が後方に
ずれ，結果として下顎頭と関節円板の位置関係がそのよう な関係になるのである。さらにその状態が悪化すると, 今 度は後方にシフトした下顎頭に関節円板が前方に押し出さ れ，関節窩内に打りる関節门板の位置がずれクローズド ロックなどを招く。

以上の概念に基づいて行った全顎的咬合治療を報告す る.

患者は 49 歳女性. 咬合の不調和および審美性の回復を 主訴として来院. 自律神経失調症で心療内科にも通院中で ある。のどの渇きも訴えている。

口腔内所見としては歯牙全歯に咬耗を認め, デンタルコ ンプレッションシンドロームによると思われる楔状欠損, いわゆるアブフラクションが多数歯に認められる. 右側に おいては上下の歯列に大きなずれを生じている。また右側 顎関節部に違和感を呈している(図 18).

術後 4 年後の現在の状態である. 自立神経失調も顎関節 の違和感も現在は消えている。ポーセレンも今のところ破 折することなく安定を維持できている(図 19).

治療の流れとしては, まず前歯部で $3 \mathrm{~mm}$ の高さでフ ラットなスプリントを装着. 顎の安定するポジションを探 り，違和感の生じない正常と思われる顎位にて MAGO 夕 
イプのスプリントに，後方へのシフトを抑制したできるか ぎりタイトなスプリントに変え，その顎位で良いのか確認 する。OKならば一気に前述した咬合接触を兼ね備えたプ ロビジョナルクラウンを装着. ウォシュアウトなどで問題 が生じていないのを確認後, 前歯から数本ずつファイナル レストレーションに移行した。

\section{結論}

天然歯列および天然歯牙形態には，いまだ秘められた未 知の部分が多々あるが，今回咬耗の生じていない天然歯列 を観察することによりその一端が見えてきた。それは上下 顎第一大臼歯にみられる顎の後方シフトを制御するダイナ ミックかつ密な咬合接触関係であり，その機能は他の臼歯 にもみられる。そこには歯牙一本一本が与えられた歯牙形 態をいかしながら決められた部位同士が密に接触してい る.この咬合接触状態こそが中枢神経系を通して垂直下し た咀嚼サイクルを維持し, 咬耗の生じない咬合状態を維持

\section{参考文献}

1）榊原功二, 佐藤貞雄：シークエンシャルオクルージョンの 臨床一下顎の後退を伴う II 級症例の咬合治療の実際一. QDT, 29 (6) : 12-28. 2004.

2) Claude R. Rufenacht 編著：ファンダメンタルス オブ エステ テイクス. 137-221, クインテッセンス出版 (東京), 1994.
できる要因であり，筆者のいう真の咬合の姿であるといえ るのではないか. 今後はさらにその奥に秘められた咬合の 核心について探究する所存である.

\section{最後に}

今回の咬合接触状態はあくまでアングル I 級で歯牙のポ ジション，骨格にも異常がない場合に適応されるものであ り，アングル II 級や III 級には歯列矯正をして歯牙のポジ ションをI 級関係に改善しないかぎり，まったく該当しな い.ただ真の咬合接触状態から生体の求めているものを探 り知ることで，アングル II 級や III 級への咬合の与え方を検 討できるのではないかと思う。垂直化が失われ水平化した 咀嚼サイクルが, 本来の歯牙形態を与えることで再び垂直 化を得ることができるのであればそれは素晴らしいことで あり，歯牙を含めた顎口腔系にとっても一番好ましいこと であると筆者は考えている。

3）佐藤貞雄, 秋本進, 不島健持, 石井穣：顎関節を考慮した 不正咬合治療．東京臨床出版，1995.

4）内藤正裕：変化する補緅。アースワークス，2005. 